\title{
Comprehensive Readiness Exam of Bachelors of Pedagogical Education in the Structure of the Independent Assessment of the Quality of Education
}

\author{
Elena U. Ilaltdinova*, Galina A. Paputkova, Irina F. Filchenkova, Irina B. Bicheva, \\ Tatyana F. Krasnopevtseva
}

Minin Nizhny Novgorod State Pedagogical University, Nizhny Novgorod, 603002, Russia

Received April 6, 2020 ; Revised June 17, 2020; Accepted July 1, 2020

Copyright $\mathrm{C} 2020$ by authors, all rights reserved. Authors agree that this article remains permanently open access under the terms of the Creative Commons Attribution License 4.0 International License

\begin{abstract}
The purpose of the study is to justify the role and content of a comprehensive readiness exam for a future teaching profession in the structure of the independent assessment of the quality of education. The results of testing assessment materials and procedures for a comprehensive readiness exam on students of the Minin University (Nizhny Novgorod, Russia) in the educational field "Education and pedagogical sciences" are presented. A comprehensive readiness exam as a component of the independent assessment of the quality of education provides a model of targeted teacher training with a control system. It can be considered a successful solution in the field of teacher training in the formation of Russian national teacher growth system. A comprehensive readiness exam is considered by the authors as a mechanism for selecting motivated and highly qualified personnel and is defined as a comprehensive exam aimed at determining the compliance of real educational results achieved with social and personal expectations about the degree of readiness to receive a pedagogical profession. The components of a comprehensive readiness exam are the student's portfolio, testing in psychology and pedagogy, and (course/training) project defense within the subject area of future pedagogical activity.
\end{abstract}

Keywords Higher Pedagogical Education, Quality of Education, Independent Quality Assessment, Comprehensive Readiness Exam, Assessment Procedures, Assessment Materials

\section{Introduction}

Independent assessment of the quality of education is an important task of functioning and developing of the modern model of higher education in Russia, ensuring compliance with the requirements of the legislation in the field of educational activity. The introduction of the updated Federal State Educational Standards (FSES) of higher education (FSES $3++$ ) and the implementation of the program for the modernization of pedagogical education allow considering quality as one of the main characteristics of education, reflecting the actual state of the education system and the prospects for its development [1]. At the same time, quality assessment acts as an element of feedback in the operational management of the education system.

Reorganization processes in the education system lead to the need to develop model criteria for assessing the quality of education as an important condition for the prospective development of the Russian education system in solving the problems of integration of the country's education and the international educational space [2-6].

This study considers the following problems: to determine the elements of the independent assessment of the quality of education and to substantiate the role and content of a comprehensive readiness exam (CRE) for a future profession in the structure of the independent assessment of educational results.

The problem of this study is updated by the modern development trends of Russian higher education, outlined in the Message of the President of Russia Vladimir Putin to the Federal Assembly of January 15, 2020.

\section{Methods}

The research methodology was based on the theoretical study of the independent assessment of the quality of 
education and its element - CRE. Analysis and generalization of the scientific and theoretical provisions on the independent assessment of the quality of education make it possible to clarify the characteristics of the studied concepts. The testing of the developed assessment procedures was carried out as part of the experimental work at the Minin University. The study involved 747 students of the Minin University in the educational field "Education and pedagogical sciences".

Various aspects of the concept of quality of education are widely reflected in scientific and theoretical research. Thus, Ushakov [7] emphasizes the role of goals and results of the quality of education depending on their level (personal, state), as well as the means of achieving results. The author proves the necessity of establishing a correspondence between the content of education and the educational technologies used and their regulatory legal, organizational, managerial, social, and pedagogical support. Methodological approaches to designing an independent assessment system of student performance are disclosed by Paputkova et al. [8]. The technological foundations for the design of assessment tools are described in the works by Perevoshchikova, Kashtanova, Perevoshchikova and Lekomtseva [9-11]. Izmailova substantiates the mechanism of interaction between employers and educational organizations in solving the problem of evaluating the results of educational programs [12]. Novikova analyzes the legal and organizational aspects of the participation of employers in assessing the quality of higher education [13]. Almost all authors emphasize the interest of employers in conducting and participating in assessment procedures, focusing on the need to develop an independent (objective) system for assessing the quality of education. Attracting employers as external experts increases the level of responsibility of teachers and students for achieving high-quality professional training results, independent work productivity, and the degree of initiative and creative solutions to professional problems $[14,15]$.

Literature analysis on the problem under study leads to the conclusion that the independence of education quality assessment is achieved by using the following elements:

- involving external experts;

- establishing clear assessment criteria;

- using indicators - measured values;

- making management decisions based on the results of the assessment.

Thus, an independent system for assessing the quality of education allows determining the conformity of educational results to the expectations and demands of employers and the educational community, as well as improving the quality of education. On the one hand, constructing such a system expands the possibilities of an educational organization in realizing the scientific, educational, professional, and creative potential of teachers and students. On the other hand, it leads to an increase in mutual responsibility for the quality of educational results.

We consider CRE as a component of the independent assessment for a future profession. This idea arose when designing a model of targeted teacher training developed by the team of the Minin University in the framework of the State Contract No. 05.015.12.0014 dated 06.17.2016 "Development of models for targeted training of teachers in the educational field 'Education and pedagogical sciences". In a dynamically developing society, this idea is timely and relevant, because, unlike previous generations, modern students are less willing to choose a profession after graduation [16]. The introduction of CRE in the educational process provides students with the opportunity to switch to another direction of training after the second year of study. This helps to build an individual vocational and educational direction for the student in accordance with personal needs and labor market demands.

In the structure of the target training model, CRE is considered from the point of view of the selection mechanism for motivated personnel and is defined as "a comprehensive exam aimed at determining the compliance of real educational results with social and personal expectations about the degree of readiness to receive a teaching profession"[6]. CRE components are tested in psychology and pedagogy, presenting the portfolio of achievements and defending a project (course/training) within the framework of the subject area of future pedagogical activity.

Testing in pedagogy and psychology is interdisciplinary, since it is designed to identify the level of formation of the cognitive and activity component of competence in the field of pedagogy and psychology. Testing can be carried out using case studies or contextual tasks that model a professional task (problem) and require research and development of solutions from the student. The subject's activity during the passage of psychological and pedagogical testing should provide the ability to comprehensively assess the level of achievement of educational results. This type of test is carried out in writing using the electronic educational environment of the Minin University $[6,17,18]$.

A student's portfolio presents documented results confirming individual achievements in various types of activities: academic performance, participation in scientific conferences, competitions, publication activity, participation in social projects, etc. The portfolio is presented orally with a demonstration of supporting documents in paper or electronic form.

The examination in the subject area is carried out in the format of the defense of the course (or training) project, which is a product of independent work. In developing the content of the project, students should provide a solution to a significant problem in the subject area of future professional activity relevant to potential employers.

The presented CRE components (testing in psychology 
and pedagogy, student portfolio, defense of a course/training project) allow fulfilling the requirements for the quality of education in terms of the actual conformity of educational conditions, the organization of the educational process, and methods for assessing educational results. In addition, the establishment of this correspondence takes into account the positions of students (motivational readiness for a future profession and individual educational results achieved), employers (optimality of educational results achieved by students and the ability to realize professional functions), and teachers (professional successes and professional results, etc.).

Since 2016, CRE has been included in the structure of the curriculum (bachelor's level of students' training) of the Minin University in the educational field "Education and pedagogical sciences" as a mandatory element in the framework of the intermediate certification of the 4 th semester of the 2 nd year. For each element of CRE, the project team of the Minin University has developed criteria and assessment indicators, fixed by the local acts of the university. All types of CRE components are subject to evaluation, each of which is evaluated on a 100-point scale. The maximum score for a CRE is 300 points. According to its results, grades are determined: “excellent" (240-300 points), "good" (165-239 points), "satisfactory" (90-164 points), "unsatisfactory" (less than 90 points). The marks "excellent", "good", and "satisfactory" are associated with successful completion of the certification test or CRE as a whole. In addition, students who score $240-300$ points are eligible for targeted training and subsequent contractual employment.

The developed assessment materials and CRE procedures were tested for two years. The study involved 747 students at the Minin University (Figure 1).

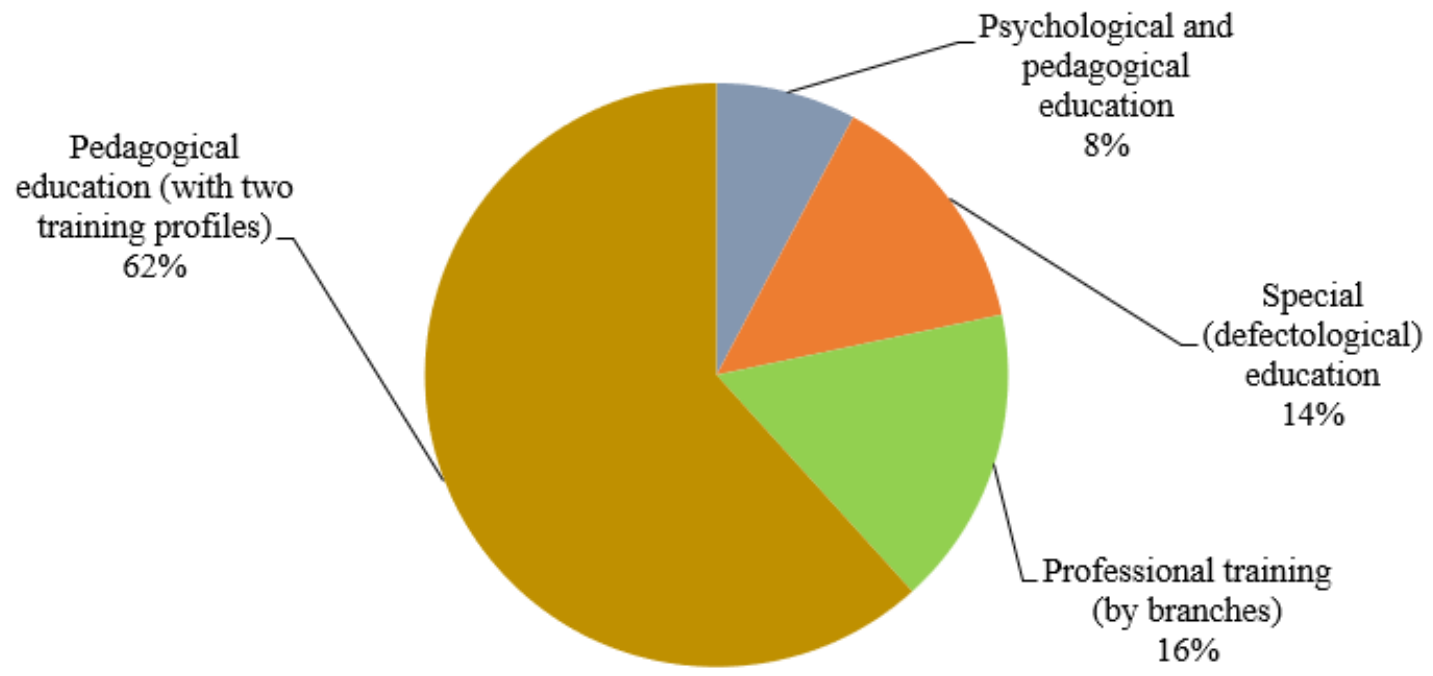

Figure 1. Distribution of participants in the testing of CRE in the specialties of the educational field "Education and pedagogical sciences" 


\section{Results}

To evaluate CRE, the following characteristics were selected:

- quality percentage;

- academic performance percentage;

- students' involvement in educational and professional activities.

The quality percentage or the share of attending students who received "good" and "excellent" marks - over 85 points in all three trials - was distributed as follows: at least $80 \%$ - students specializing in psychological and pedagogical education and professional training (by branches), at least $80 \%$ - students specializing in pedagogical education and special (defectological) education (Figure 2).

The percentage of performance or the share of attending students who received the results of all three tests with the marks "satisfactory", "good", "excellent" (more than 72 points) amounted to $92 \%$. The greatest results were shown by students specializing in special (defectological) education $(97 \%)$.

For the "quality percentage" and "academic performance percentage" indicators, the value of standard deviation was calculated. For the quality indicator, the standard deviation was $4.0 \%$, for the indicator of academic performance $-4.7 \%$, which characterized the average deviation of the actual value of the attribute from their average value. In most study groups, these values were near the average.

The characteristic of the student's involvement in educational and professional activities occurred according to typologized groups based on motivation and competencies:

"They can, but they don't want to" (the average percentage of students who received more than 85 points for testing, but less than 72 points for the portfolio);

"They want, but they can't" (average percentage of students who received more than 85 points for the portfolio, but less than 72 points for testing);

"They want and they can" (the average percentage of students who received more than 85 points for all three elements of the CRE);

"They don't want and they can't" (average percentage of students who received less than 55 points for all three elements of CRE).

The distribution of attending students by categories of inclusion in educational and professional activities is presented in Figure 3.

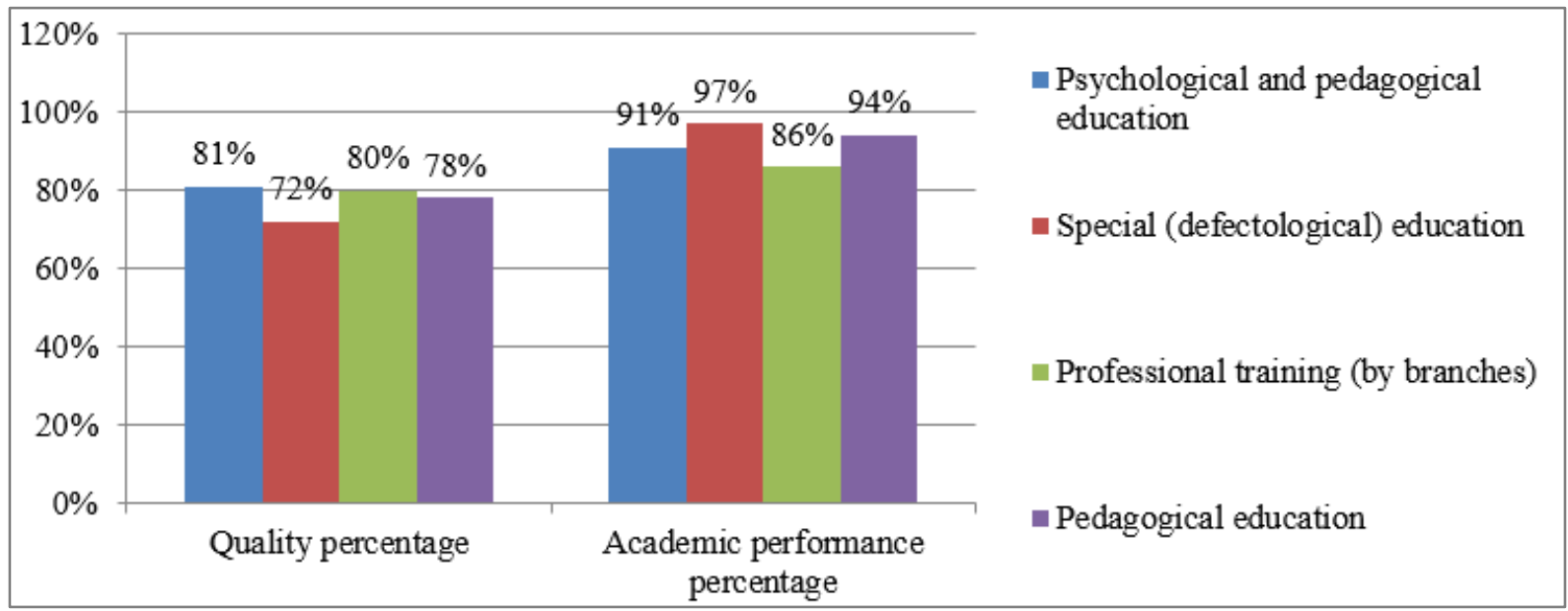

Figure 2. Description of the results of the CRE in the areas of training

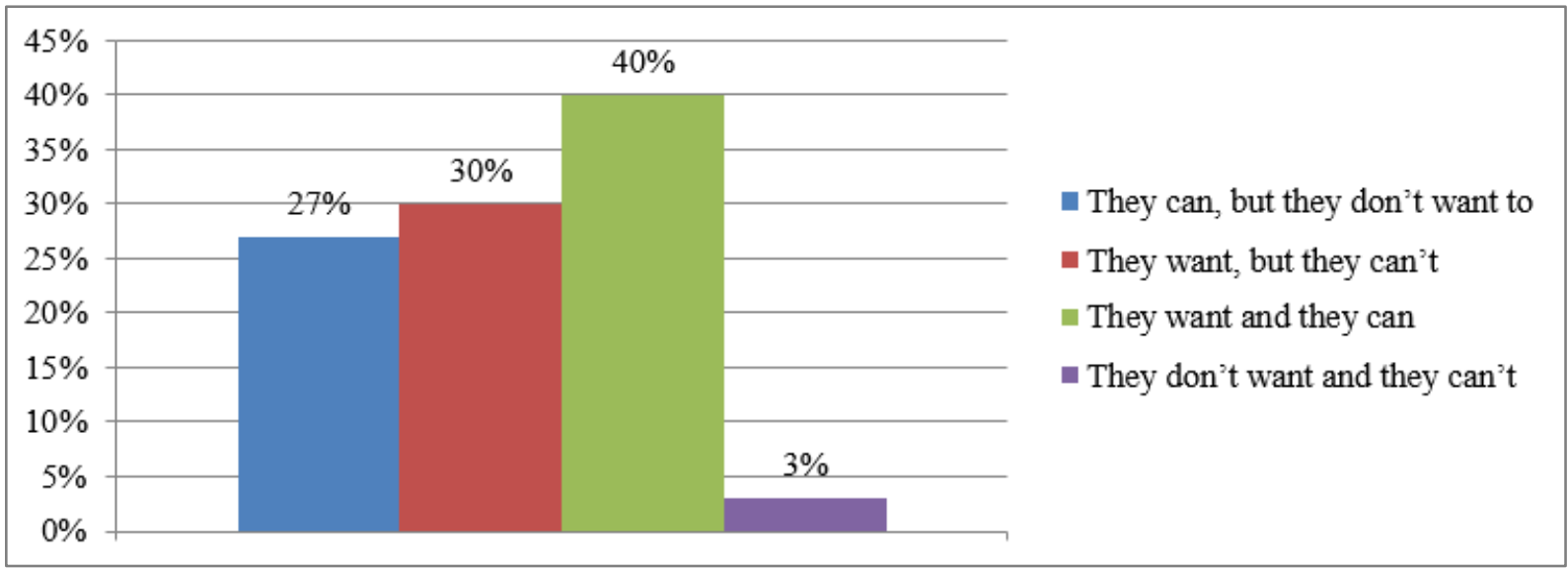

Figure 3. Characteristics of the involvement of students in educational and professional activities 
In the first group "They can, but they don't want to", $27 \%$ of the attendees showed a high level of theoretical psychological and pedagogical training at the exam, but a low level of motivational component, which was reflected in the absence of motives to engage in personal and professional self-improvement. On the contrary, the percentage of students with a high level of motivational readiness to participate in various types of activities and showing a low level of theoretical training amounted to $30 \%$ of the number of the participants in CRE. The greatest prospects in the selection for the targeted training program for teachers were identified among students who were categorized as "They want and can". This group was the largest $-40 \%$, which allows selecting for a targeted training program the most motivated and professionally trained students. Particular attention should be paid in the educational process to students of the fourth group - "They do not want and cannot", which made up $3 \%$ of the total number of CRE participants.

The students participating in the CRE were asked to evaluate the level of objectivity of each component of the exam. The students consider the project defense to be the most objective component of the CRE: $84 \%$ rated the level of objectivity as high, $16 \%$ - as average. For testing, the data was as follows: $76 \%$ of respondents noted a high level of objectivity of this element of the exam, $23.7 \%$ noted an average level, $0.30 \%$ indicated a low level. The lowest grade was given to such an element as a portfolio: $61 \%$ of respondents noted a high level of objectivity of this element of the exam, $29 \%$ noted an average level, $10 \%$ indicated a low level. This fact requires more thorough study of the evaluation criteria and requirements for compiling a portfolio by the university.

It was also interesting to evaluate the format of the exam on the part of the employers participating in the CRE examination board. More than $80 \%$ of the examination board members highly appreciated the structure of CRE in terms of the ability to assess the formation of the professional orientation of the individual. They noted the reflection in case studies of problematic situations that arose in modern educational institutions. The development of solutions to such cases allows assessing the level of psychological and pedagogical knowledge required to work with various categories of students, taking into account their personal characteristics and age.

Thus, the results of the CRE in the educational field "Education and pedagogical sciences" allow solving a set of tasks:

- to assess the individual capabilities of students in educational, research, design, social, and other activities;

- to establish the degree of motivation of students and their readiness to master future professional activities in accordance with the requirements of the FSES and potential employers;

- to assess the level of achievement by graduates of the necessary educational results that affect the formation of professional abilities.

\section{Conclusions}

The results of the study allow drawing the following conclusions.

First, CRE as one of the components of the independent assessment of the quality of education provides a model of targeted teacher training with a control system. It can be considered a successfully designed and tested solution in the mainstream of teacher training in the formation of the Russian national teacher growth system. The proposed system implements the principles of openness, voluntariness, as well as an integrated approach, which is a prerequisite for the effectiveness of training the teacher elite in Russia.

Second, the implementation of CRE assessment procedures allows for the independent assessment of the quality of educational results having achieved that meet the necessary regulatory requirements and the requirements of potential employers, helping to solve the problem of the qualitative selection of students and their retention in the profession.

Third, the applied assessment procedures are aimed at improving the pedagogical skills of teachers and the formation of high motivational, psychological, and pedagogical readiness of bachelors of pedagogical education at the stage of entry into the pedagogical profession and orientation of students to continuous self-education.

The prospect of further research involves the implementation of the developed assessment procedures in the practice of pedagogical universities of the Russian Federation with the aim of testing.

\section{Acknowledgements}

The authors owe appreciation for the help in collecting data of the research to the project's scientific supervisor A. A. Fedorov, Doctor of Philosophy, Professor, Rector of the Immanuel Kant Baltic Federal University.

The presented results of testing assessment materials and procedures for a comprehensive readiness exam with students being future bachelors of the Minin University in the areas of training UGSN 44.00.00 "Education and Pedagogical Sciences" were obtained as part of the implementation of the State Contract No. 05.015.12.0014 dated 06.17.2016 "Development of models for targeted training of teachers in the educational field "Education and pedagogical sciences". 


\section{REFERENCES}

[1] T. Balykbaev, G. Primbetova. Sistema vneshnei otsenki kachestva obrazovaniia kak element natsionalnoi otsenki kachestva obrazovaniia [The System of External Assessment of the Quality of Education as an Element of the National System for Assessing the Quality of Education], Pedagoicheskie izmereniia [Educational Measurement], Vol. 1, 19-26, 2011.

[2] I. B. Bicheva, S. N. Kaznacheeva. Usloviia formirovaniia gotovnosti obuchaushikhsia k konkurentnoi professionalnoi deiatelnosti [Conditions for the Formation of Student's Readiness for Competitive Professional Activity], Nauka i praktika regionov [Science and Practice of the Regions], Vol. 2, No. 15, 58-62, 2019.

[3] I. B. Bicheva, A. V. Khizhnaia, S. V. Desiatova. Akmeologicheskiie osnovaniia professionalnogo razvitiia pedagogov doshkolnogo obrazovaniia [Acmeological Basis for the Professional Development of Preschool Educators], Perspektivy Nauki i Obrazovania [Prospects for Science and Education], Vol. 2, No. 32, 48-53, 2018.

[4] E. B. Gafforova, T. I. Eliseeva, L. D. Maslova. Formirovanie osnoc nezavisimoi otsenki kachestva obrazovaniia vypusknikov [Formation of the Foundations of the independent assessment of the quality of education of Graduates], Natsionalnye interesy: prioritety i bezopastnost [National interests: Priorities and Security], Vol. 8, No. 46(187), 58-64, 2012.

[5] S. M. Markova, S. A. Tsyplakova, C. P. Sedykh, A. V. Khizhnaya, O. N. Filatova. Forecasting the Development of Professional Education, Lecture Notes in Networks and Systems, Vol. 91, 452-459, 2020.

[6] A. A. Fedorov, G. A. Paputkova, E. Y. Ilaltdinova, I. F. Filchenkova, M. Y. Solovev. Model for employer-sponsored education of teachers: opportunities and challenges, Man in India, Vol. 97, No. 11, 101-114, 2017.

[7] B. G. Ushakov. Kachestvo obrazovaniia i/ili obrazovaniia kachestva (problemy, metodologii, praktiki i otsenki) [The Quality of Education and/or Formation of Quality (Problems, Methodologies, Practices and Assessments)], Upravlencheskoe konsultirovaniie. Aktualnye problem gosudarstvennogo i munitsipalnogo upravleniia, Vol. 3, No. 31, 149-161, 2008.

[8] G. A. Paputkova, E. P. Sedykh, O. A. Orlova. Proektirovaniie sistemy nezavisimoi otsenki kachestva deiatelnosti studentov $\mathrm{v}$ protsesse promezhutochnoi attestatsii [Designing an Independent Assessment System for the Quality of Student's Activities in the Process of Intermediate Certification]. Sovremennye problem nauki i obrazovaniia, Vol. 4, 242, 2015.

[9] E. N. Perevoshchikova, S. N. Kashtanova. Proekt kak forma itogovoi attestatsii po obrazovatelnomu moduliu [Project as a Form of Final Certification in the Educational Module], Vysshee obrazovaniie segodnia, Vol. 4, 17-22, 2015.

[10] E. N. Perevoshchikova. Kontseptualnye osnovy konstruirovaniia sredstv dlia otsenivaniia obrasovatelnykh resultatov [Conceptual Basis for the Design of Tools for Assessing Educational Results], Vestnik of Minin
University, Vol. 2, No. 15, 13, 2016.

[11] E. N. Perevoshchikova, A. A. Lekomtseva. Konstruirovanie kontekstnogo zadaniia dlia otsenki dostizheniia obrazovatelnykh resultatov [Construction of a Contextual Task for Assessing the Achievement of Educational Results], Vestnik of Minin University, Vol. 4, No. 17, 29, 2016.

[12] M. A. Izmailova. Problemy nezavisimoi otsenki kachestva obrazovaniia [Problems of the independent assessment of the quality of education], Vestnik Finansovogo universiteta, Vol. 1, No. 85, 103-111, 2015.

[13] N. V. Novikova. Ob uchastii rabotodatelei v otsenke kachestva vysshego obrazovaniia: pravovoi i organizatsionnye aspekty [On the Participation of Employers in Assessing the Quality of Higher Education: Legal and Organizational Aspects], Vestnik Permskogo gosudarstvennogo gumanitarno-pedagogicheskoouniversite ta. Series No. 1. Psilkhologicheskie i pedagogicheskie nauki, Vol. 1, 90-94, 2014.

[14] E. G. Gutsu, N. N. Demeneva, E. V. Kochetova, O. V. Kolesova, T. V. Mayasova. Subjective Representation Study of University Teachers About the Significance of Changes in Higher Education, Lecture Notes in Networks and Systems, Vol. 91, 439-445, 2020.

[15] I. F. Filchenkova. Educational management of innovative activity of teachers as an object of pedagogical research, Vestnik of Minin University, Vol. 7, No. 4, p. 3, 2019.

[16] A. S. Kurbatova, I. B. Bicheva, N. V. Ivanova, S. A. Zaitseva, L. V. Krasilnikova. Career guidance problem as a systemic problem in russian society, Revista Inclusiones, Vol. 7, 158-173, 2020.

[17] E. K. Samerkhanova, L. N. Bakhtiyarova, A. V. Ponachugin, E. P. Krupoderova, K. R. Krupoderova. Project Activities of University Students by Means of Digital Technologies, Lecture Notes in Networks and Systems, Vol. 91, 460-467, 2020.

[18] A. A. Fedorov, G. A. Paputkova, I. F. Filchenkova, E. Y. Ilaltdinova, M. I. Klyueva. Open digital education space: classification of E-services at university, International Journal of Recent Technology and Engineering, Vol. 8 No. 2, 2495-2498, 2019.

[19] E. P. Sedykh. Sistema normativnogo pravovogo obespecheniia proektnogo upravleniia $\mathrm{v}$ obrazovanii [The System of Normative and Legal Support for Project Management in Education], Vestnik of Minin University, Vol. 7, No. 1(26), 1, 2019.

[20] A. A. Fedorov. Tselevaia podgotovka pedagogov: model kadrovogo konstruktora regionalnogo sotsialno-pedagogich eskogo klastera: monografiia. [Targeted Training of Teachers: Model of the Personnel Designer of the Regional Sociopedagogical Cluster: Monograph], Nizhny Novgorod, Minin University, 204, 2017.

[21] N.V. Belinova, I.B. Bicheva, L.V. Krasilnikova, T.G. Khanova, A.V. Hizhnaya. The Role of Managerial Competence of an Executive in Improving the Quality of Pre-school Educational Organization, Lecture Notes in Networks and Systems, Vol. 91, 422-429, 2020. 